\title{
Anatomical Parameters of the Rectus Capitis Posterior Major and Obliqus Capitis Inferior Muscles Based on an Oblique Sagittal Magnetic Resonance Scan Method
}

\author{
Parámetros Anatómicos de los Músculos Recto Posterior Mayor de la Cabeza y Oblicuo Mayor \\ de la Cabeza Basados en un Método Oblicuo Sagital de Exploración por Resonancia Magnética
}

\author{
Qiang Xu' ${ }^{1}$ : Lin $\mathrm{Cai}^{2}$; Cong Liu' ${ }^{1}$; Ying Zhang²; Okoye Chukwuemeka Samuel²; \\ Nan Zheng'; ${ }^{2}$ Yan-Yan $\mathrm{Chi}^{2}$; Sheng-Bo Yu² \& Hong-Jin Sui ${ }^{2}$
}

XU, Q.; CAI, L.; LIU, C.; ZHANG, Y.; SAMUEL, O. C.; ZHENG, N.; CHI, Y. Y.; YU, S. B. \& SUI, H. J. Anatomical parameters of the rectus capitis posterior major and obliqus capitis inferior muscles based on an oblique sagittal magnetic resonance scan method. Int. J. Morphol., 36(3):921-925, 2018.

SUMMARY: The deep suboccipital muscles has been shown to connect the spinal dura mater via dense connective tissue termed the myodural bridge (MDB). The MDB has both physiological and clinical implications. Data on morphological and imaging anatomical parameters of the deep suboccipital muscles are scare. In this study, T2-weighted images of rectus capitis posterior major (RCPma) and obliqus capitis inferior (OCI) of 109 healthy adults were obtained by 0 -degree sagittal and 30-degree oblique sagittal continuous MRI scanning of the head and neck of the subjects. Sectional area parameters of the RCPma and the OCI were measured. The 0-degree sagittal section was measured with $5 \mathrm{~mm}$ bias from the median sagittal plane, the sectional area of the RCPma was $186.34 \pm 55.02 \mathrm{~mm}^{2}$ on the left, and $202.35 \pm 59.76 \mathrm{~mm}^{2}$ on the right. The sectional area of OCI was $221.72 \pm 68.99 \mathrm{~mm}^{2}$ on the left, and $224.92 \pm 61.34 \mathrm{~mm} \mathrm{on}^{2}$ the right; At the section with 30-degree bias from the oblique sagittal plane, the sectional area of RCPma was $183.30 \pm 42.24 \mathrm{~mm}^{2}$ in males, and $133.05 \pm 26.44 \mathrm{~mm}^{2}$ in females. The sectional area of OCI was $254.81 \pm 46.20 \mathrm{~mm}^{2}$ in males, and $167.42 \pm 27.85 \mathrm{~mm}^{2}$ in females. Significant sex difference exists in the sectional areas of the RCPma and OCI, the values of the male subjects were predominantly larger $(\mathrm{P}<0.05)$, however there were no age- related significant difference. The sectional area of RCPma is bilateral asymmetric, the RCPma on the right side is larger than that of the left side $(\mathrm{P}<0.05)$, but the OCI is bilaterally symmetric $(\mathrm{P}>0.05)$. The MRI image features, imaging anatomical data and sexual dimorphism of the RCPma and the OCI are presented in this study. This imaging anatomical data will be useful for functional and clinical studies on the RCPma, OCI, and the MDB.

KEY WORDS: Suboccipital region; Rectus capitis posterior major (RCPma); Obliqus capitis inferior(OCI); Imaging anatomy parameters.

\section{INTRODUCTION}

The deep suboccipital muscles including the rectus capitis posterior major (RCPma), rectus capitis posterior minor (RCPmi), obliquus capitis superior (OCS), and obliqus capitis inferior (OCI), located between the inferior nuchal line of the occipital bone and the dorsal aspect of the axis, are indispensable in maintaining head posture and in proprioception. Hack et al. (1995) first proposed the concept of the myodural bridge (MDB) as a dense fibrous connection between the RCPmi,posterior atlanto-occipital membrane (PAOM) and dura mater (DM) Hack et al., 1995. Subsequent researches have shown that the RCPma (Scali et al., 2013),
OCI (Pontell et al., 2013) and ligamentum nuchae (LN) participate in forming the MDB. Researchers believe that these deep suboccipital muscles via the MDB perform important physiological roles such as preventing DM in folding, keeping the cerebellomedullary cistern patent and maintaining the normal flow of cerebrospinal fluid (CSF),transmitting DM tension and adjusting head posture (Hack et al., 1995). Recently, Sui et al., proposed that the MDB may be a dynamic source of CSF circulation (Sui et al., 2013; Zheng et al., 2014). Some clinical studies suggested that there is a relationship between the deep

\footnotetext{
${ }^{1}$ Department of Radiology, Huanghai Hospital, Dalian, Liaoning 116021, China.

${ }^{2}$ Department of Anatomy, Dalian Medical University, Dalian, Liaoning 116044, China.

This work was supported by Natural Science Foundation of China (NSFC31600972, NSFC31571234).
} 
suboccipital muscles and headache (McPartland et al., 1997; Fernández-de-Las-Peñas et al., 2007, 2008). To understand the morphology and human distribution characteristics of RCPmiRCPma and OCI, imaging anatomical data is significantly meaningful in functional studies of the MDB,especially in identifying pathologic changes of the deep suboccipital muscles.

Based on the MRI imaging on healthy adults, $\mathrm{Xu}$ et al. (2013) provided an imaging reference values of the length and sectional area of the RCPmi in male and female subjects. However, morphological data on the RCPma and OCI in healthy adults have not been reported to date. In this study, T2-weighted MRI images was used to measure the RCPma and OCI in healthy adults. This study provides morphometric data on RCPma and OCI in healthy adults, and lays a foundation for functional and clinical research on the suboccipital muscles.

\section{MATERIAL AND METHOD}

Approval for this study was obtained from the Ethics Committee for Research of Basic Medical College of Dalian Medical University. One hundred and nine (109) healthy adults including 47 males (age range from 19 to 70 with an average of $40.0 \pm 14.1$ years) and 62 females (age range from 20 to 67 years with an average of $38.1 \pm 13.9$ years) participated in this study.

Scanning equipment and parameters. A 0.35T MRI scanner (BTI-035, Shengzhen Basda Medical Apparatus Co., Ltd.) was used with a neck coil phased array. The scanning sequence T2WI/FSE (TR/TE 3,200 ms/ $115 \mathrm{~ms}$ ) was employed with a thickness of $5 \mathrm{~mm}$, interval of $1 \mathrm{~mm}, 256$ X 279 matrix, 272 X $272 \mathrm{~mm}$ view field, and two activations.
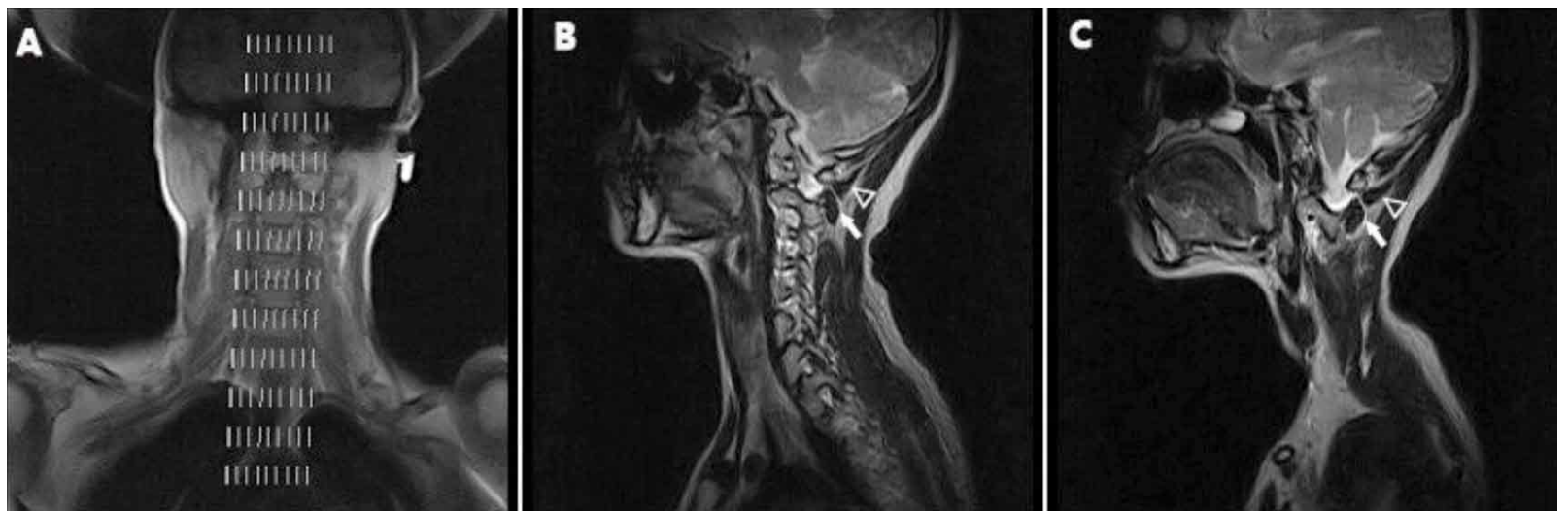

Fig 1.The MR scanning reference lines and bilateralT2WI image with $5 \mathrm{~mm}$ bias from the median sagittal plane. A. The MR scanning reference lines B. Left T2WI image with $5 \mathrm{~mm}$ bias from the median sagittal plane C. Right T2WI image with $5 \mathrm{~mm}$ bias from the median sagittal plane. $\Delta$ Cross section of RCPma. $\leftarrow$ Cross section of OCI
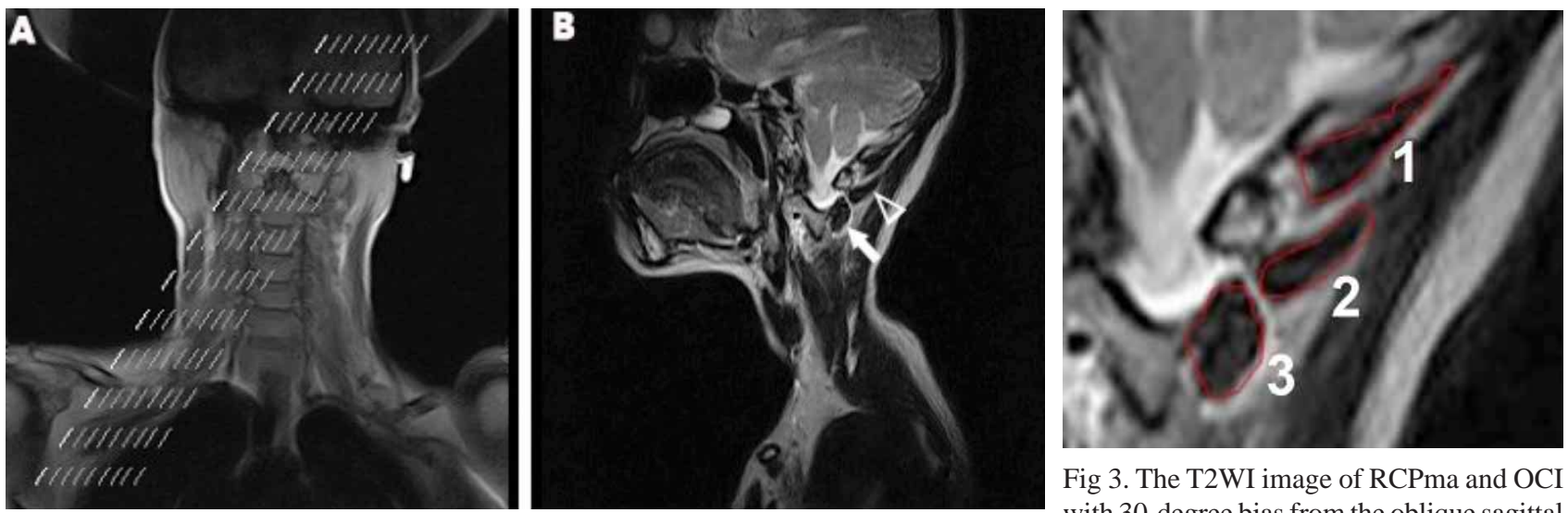

Fig 3. The T2WI image of RCPma and OCI with 30-degree bias from the oblique sagittal

Fig 2.The MR scanning reference lines and T2WI image including suboccipital muscles plane (The sctional area of RCPma is with 30-degree bias from the oblique sagittal plane A. The MR scanning reference lines B. maximum). 1. RCPmi, 2.RCPma, 3OCI; The T2WI image with 30-degree bias from the oblique sagittal plane including suboccipital range of area measurement representing the muscle. The sectional area of RCPma is maximum. $\Delta$ Cross section of RCPma. $\leftarrow$ Cross muscle cross-section was outlined by the red section of OCI. line. 
Image acquisition. Bilateral 0-degree (sagittal) and 30degree oblique sagittal scanning sectional areas of RCPma and OCIwas imaged by T2-weighted scanning as stipulated by $\mathrm{Xu}$ et al. The bilateral 0-degree (sagittal) scanning sectional area of RCPma and OCI has five millimeter bias from the median sagittal plane, and the 30-degree oblique sagittal scanning sectional area of RCPma and OCI is in the plane with the maximum area of RCPma.

Table I. The sectional area of the RCPma with 0-degree bias from oblique sagittal plane $\left(\mathrm{mm}^{2}\right)$.

\begin{tabular}{lll}
\hline Value & Left $(\mathrm{n}=109)$ & Right $(\mathrm{n}=109$ \\
\hline Ranges & $93.14-353.10$ & $92.01-391.73$ \\
$95 \%{ }^{\circ}$ confidence intervals & $175.90-196.79$ & $191.01-213.70$ \\
Mean \pm SD & $186.34 \pm 55.02$ & $202.35 \pm 59.76$ \\
$P$ value & & 0.000
\end{tabular}

Table II. The sectional area of the OCI with 0-degree bias from oblique sagittal plane. $\left(\mathrm{mm}^{2}\right)$.

\begin{tabular}{lcl}
\hline Value & Left $(\mathrm{n}=109)$ & Right $(\mathrm{n}=109)$ \\
\hline Ranges & $110.63-403.67$ & $111.77-390.85$ \\
$95 \%{ }^{\circ}$ confidence intervals & $208.62-234.82$ & $213.27-236.57$ \\
Mean \pm SD & $221.72 \pm 68.99$ & $224.92 \pm 61.34$ \\
P value & 0.368 & \\
\hline
\end{tabular}

Table III. The sectional area of the RCPma with 30-degree bias from oblique sagittal plane. $\left(\mathrm{mm}^{2}\right)$.

\begin{tabular}{lll}
\hline Value & Male $(\mathrm{n}=47)$ & Female $(\mathrm{n}=62)$ \\
\hline Ranges & $118.38-276.58$ & $77.90-206.75$ \\
$95 \%{ }^{\circ}$ confidence intervals & $171.19-195.40$ & $126.33-139.76$ \\
Mean \pm SD & $183.30 \pm 42.24$ & $133.05 \pm 26.44$ \\
$P$ value & \multicolumn{2}{c}{0.000} \\
\hline
\end{tabular}

Table IV. The sectional area of the OCI with 30-degree bias from oblique sagittal plane. $\left(\mathrm{mm}^{2}\right)$.

\begin{tabular}{lll}
\hline Value & Male $(\mathrm{n}=47)$ & Female $(\mathrm{n}=62)$ \\
\hline Ranges & $166.52-359.56$ & $119.10-229.73$ \\
$95 \%{ }^{\circ}$ confidence intervals & $241.25-268.38$ & $160.35-174.50$ \\
Mean \pm SD & $254.81 \pm 46.20$ & $167.42 \pm 27.85$ \\
P value & \multicolumn{2}{c}{0.000} \\
\hline
\end{tabular}

Measurement of RCPma and OCI sectional area. The boundary of selected sagittal and oblique sagittal scanning images of RCPma and OCI was identified via MR Workstation PACS system, and the sectional area of the muscles was measured automatically.

Analysis of data. The range, $95 \%$ confidence interval, mean, and standard deviation of the morphological parameters of the RCPma and OCI were calculated. Comparisons between the sexes were tested using OneWay ANOVA analysis and the bilateral symmetry of muscles were tested using a paired sample T-test. A p value of less than 0.05 indicated a statistically significant difference.

\section{RESULTS}

The MR images of 109 healthy adults were collected via 0-degree (sagittal) and 30-degree oblique sagittal MRI scanning angle of the nape. In the section with $5 \mathrm{~mm}$ bias from the median sagittal plane, the RCPma is a narrow triangle or prolate spindle shaped,the parameters of sectional area are $93.14-353.10 \mathrm{~mm}^{2}$ on the left and 92.01$391.73 \mathrm{~mm}^{2}$ on the right with a significant difference $(\mathrm{P}<0.05)$. (Table I). The OCI is found to be spindle shaped, and the sectional area parameters are $110.63-403.67 \mathrm{~mm}^{2}$ on the left and $111.77-390.85 \mathrm{~mm}^{2}$ on the right with no significant difference $(\mathrm{P}>0.05)$ (Table II). In the section with 30-degree bias from the oblique sagittal plane, the RCPma has the shape of an elongated triangle, the sectional area parameters are $183.30 \pm 42.24 \mathrm{~mm}^{2}$ in males and $133.05 \pm 26.44 \mathrm{~mm}^{2}$ in females with a significant sex difference $(\mathrm{P}<0.0)$ (Table III). The OCI is oval shaped,the sectional area parameters are $254.81 \pm 46.20 \mathrm{~mm}^{2}$ in males and $167.42 \pm 27.85 \mathrm{~mm}^{2}$ in females with a significant sex difference $(\mathrm{P}<0.05)$ (Table IV).The sectional areas of RCPma and OCI present no significant difference between the group greater than 45 years old and less than or equal to 45 years old in males or females. (Tables V and VI).

Table V. The comparsion of sectional area of the RCPma with 30-degree bias from oblique sagittal plane in different age groups. $\mathrm{mm}^{2}$

\begin{tabular}{lcccc}
\hline Value & \multicolumn{2}{c}{ Male $(\mathrm{n}=47)$} & \multicolumn{2}{c}{ Female $(\mathrm{n}=62)$} \\
& $\leq 45$ years old $(\mathrm{n}=32)$ & $>45$ years old $(\mathrm{n}=15)$ & $\leq 45$ years old $(\mathrm{n}=40)$ & $>45 y e a r s$ old $(\mathrm{n}=22)$ \\
\hline Ranges & $124.9-273.2$ & $118.38-276.58$ & $77.9-206.8$ & $99.6-202.9$ \\
$95 \%{ }^{\circ}$ confidence intervals & $136.73-202.07$ & $146.69-213.91$ & $134.4-159.7$ & $138.9-168.2$ \\
Mean \pm SD & $169.4 \pm 26.5$ & $180.3 \pm 34.8$ & $147 \pm 37.9$ & $153.6 \pm 30.3$ \\
P value & & 0.47 & & 0.519 \\
\hline
\end{tabular}


XU, Q.; CAI, L.; LIU, C.1; ZHANG, Y.; SAMUEL, O. C.; ZHENG, N.; CHI, Y. Y.; YU, S. B. \& SUI, H. J. Anatomical parameters of the rectus capitis posterior major and obliqus capitis inferior muscles based on an oblique sagittal magnetic resonance scan method. Int. J. Morphol., 36(3):921-925, 2018.

Table VI. The comparsion of sectional area of the OCI with 30-degree bias from oblique sagittal plane in different age groups. $\mathrm{mm}^{2}$

\begin{tabular}{lcccc}
\hline Value & \multicolumn{2}{c}{ Male $(\mathrm{n}=47)$} & \multicolumn{2}{c}{ Female $(\mathrm{n}=62)$} \\
& $\leq 45$ years old $(\mathrm{n}=32)$ & $>45$ years old $(\mathrm{n}=15)$ & $\leq 45$ years old $(\mathrm{n}=40)$ & $>45 \mathrm{years}$ old $(\mathrm{n}=22)$ \\
\hline Ranges & $116.52 \pm 359.56$ & $120.45 \pm 330.57$ & $119.1 \pm 229.73$ & $123.57 \pm 219.49$ \\
$95 \%{ }^{\circ}$ confidence intervals & $211.53-258.16$ & $187.48-272.01$ & $160.89-179.10$ & $144.54-187.21$ \\
Mean \pm SD & $234.8 \pm 61.29$ & $229.75 \pm 66.51$ & $169.9 \pm 27.31$ & $165.87 \pm 33.58$ \\
$P$ value & & 0.814 & & 0.669 \\
\hline
\end{tabular}

\section{DISCUSSION}

This study collected the T2-weighted MR images of the RCPma and OCI of 109 healthy adults via 0-degree (sagittal) and 30-degree oblique sagittal continuous MRI scanning. The MR image features and imaging anatomical data of RCPma and OCI was acquired. Significant sex difference was found in the sectional areas of RCPma and OCI respectively, those of males were significantly higher than females. Xu et al. also found significant sex differences in the MRI parameters of RCPmi. In this study, we also found that the RCPma was bilateral asymmetric, the sectional area on the right is larger than that of the left, but the OCI is symmetric. The discrepancy in the left and right RCPma may be influenced by head posture and handedness. The sectional areas of RCPma and OCI present no significant difference between the group greater than 45 years old and less than or equal to 45 years old. Studies by Xu et al. found that the parameters of the RCPmi was not age related which implies that the deep suboccipital muscles do not significantly atrophy due to normal aging.

Since the concept of the MDB was conceived Hack et al., (1995), the functions of the deep suboccipital muscles have been extended. The MDB is proposed to prevent DM folding, maintaing patency of the subarachnoid space and the normal flow of cerebrospinal fluid(CSF), transmitting tension of DM and adjusting the head position (Hack et al., 1995; Scali et al., 2015). Recently, Sui et al. proposed that the MDB may be a dynamic source of CSF circulation in the spinal subarachnoid space (Sui et al.; Zheng et al.). The RCPmi is connected to the cervical spinal dura mater via the MDB through the PAOM (Hack et al., 1995; Rutten et al., 1997; Alix et al., 1999; Nash et al., 2005; Zumpano et al., 2006; Scali et al., 2015; Yuan et al., 2016) and the RCPma and OCI is connected to the cervical spinal dura mater via the MDB through the posterior atlanto-axial membrane (PAAM) (Hack et al., 1995; Rutten et al.; Alix et al.; Nash et al.; Zumpano et al.; Scali et al., 2005; Yuan et al.). The connections between these structures are speculative anatomic bases for the above functions and may be of clinical significance. Literatures put forward that chronic headache is associated with pathological changes of the MDB and RCPmi (McPartland et al.; Alix et al.; Fernández-de-LasPeñas et al., 2007, 2008), when lesion occurs in the RCPmi, and the DM which is pain sensitive is pulled, headache may occur (Hack et al., 2004) This study presented the MRI image features, imaging anatomical data and sexual dimorphism of RCPma and OCI. Moreover, this imaging anatomical data will be useful for functional and clinical studies on RCPma, OCI, patients with muscular atrophy and neck pain,and the MDB.

\section{CONCLUSION}

The study presented the MR image features and imaging anatomical data of the RCPma and OCI in healthy adults.Significant sex difference exist in the RCPma and OCI muscles respectively.However, there was no age-related significant difference. This study also showed that the RCPma is bilaterally asymmetric.

XU, Q.; CAI, L.; LIU, C.; ZHANG, Y.; SAMUEL, O. C.; ZHENG, N.; CHI, Y.; YU, S. B. \& SUI, H. J. Parámetros anatómicos de los músculos recto posterior mayor de la cabeza y oblicuo mayor de la cabeza basados en un método oblicuo sagital de exploración por resonancia magnética. Int. J. Morphol., 36(3):921-925, 2018.

RESUMEN: Se ha demostrado que los músculos suboccipitales profundos conectan la duramadre espinal a través del tejido conectivo denso denominado puente miodural (PMD). El PMD tiene implicaciones tanto fisiológicas como clínicas. Los datos sobre los parámetros anatómicos y morfológicos y de imagen de los músculos suboccipitales profundos son alarmantes. En este estudio, se obtuvieron imágenes ponderadas en T2 del músculo recto posterior mayor (RCPma) y del músculo oblicuo mayor de la cabeza (OCI) de 109 adultos sanos, mediante una exploración de la cabeza y el cuello sagital de 0 grados y sagital oblicua de 30 grados. Se midieron los parámetros de área seccional del RCPma 
y el OCI. La sección sagital de 0 grados se midió con un sesgo de $5 \mathrm{~mm}$ desde el plano mediano, el área de la sección de la RCPma fue $186,34 \pm 55,02 \mathrm{~mm}^{2}$ a la izquierda y $202,35 \pm 59,76 \mathrm{~mm}^{2}$ a la derecha. El área seccional de OCI fue $221.72 \pm 68.99 \mathrm{~mm}^{2}$ a la izquierda y $224.92 \pm 61.34 \mathrm{~mm}^{2}$ a la derecha. En la sección de 30 grados desde el plano sagital oblicuo, el área de la sección de RCPma fue de $183.30 \pm 42.24 \mathrm{~mm}^{2}$ en los hombres, y $133.05 \pm$ $26.44 \mathrm{~mm}^{2}$ en las mujeres. El área seccional de OCI fue de 254.81 $\pm 46.20 \mathrm{~mm}^{2}$ en varones y $167.42 \pm 27.85 \mathrm{~mm}^{2}$ en mujeres. Existe una diferencia significativa según el sexo en las áreas seccionales de la RCPma y la OCI, los valores de los sujetos masculinos fueron predominantemente mayores $(\mathrm{P}<0.05)$. Sin embargo, no hubo diferencia significativa relacionada con la edad. El área de la sección de RCPma es bilateral asimétrica, la RCPma en el lado derecho es más grande que la del lado izquierdo $(\mathrm{P}<0.05)$, pero el OCI es bilateralmente simétrico ( $\mathrm{P}>0.05)$. Las características de la imagen de resonancia magnética, los datos anatómicos de imágenes y el dimorfismo sexual de la RCPma y la OCI se presentan en este estudio. Estos datos anatómicos de imágenes serán útiles para estudios funcionales y clínicos en RCPma, OCI y PMD.

PALABRAS CLAVE: Región suboccipital; Músculo recto posterior mayor de la cabeza; Músculo oblicuo mayor de la cabez; Imágenes.

\section{REFERENCES}

Alix, M. E. \& Bates, D. K. A proposed etiology of cervicogenic headache: the neurophysiologic basis and anatomic relationship between the dura mater and the rectus posterior capitis minor muscle. J. Manipulative Phsyiol. Ther, 22(8):534-9, 1999.

Fernández-de-Las-Peñas, C.; Bueno, A.; Ferrando, J.; Elliott, J. M.; Cuadrado, M. L. \& Pareja, J. A. Magnetic resonance imaging study of the morphometry of cervical extensor muscles in chronic tension-type headache. Cephalalgia, 27(4):355-62, 2007.

Fernández-de-Las-Peñas, C.; Cuadrado, M. L.; Arendt-Nielsen, L.; Ge, H. Y. \& Pareja, J. A. Association of cross-sectional area of the rectus capitis posterior minor muscle with active trigger points in chronic tensiontype headache: a pilot study. Am. J. Phys. Med. Rehabil., 87(3):197203, 2008.

Hack, G. D. \& Hallgren, R. C. Chronic headache relief after section of suboccipital muscle dural connections: a case report. Headache, 44(1):84-9, 2004.

Hack, G. D.; Koritzer, R. T.; Robinson, W. L.; Hallgren, R. C. \& Greenman, P. E. Anatomic relation between the rectus capitis posterior minor muscle and the dura mater. Spine (Phila Pa 1976), 20(23):2484-6, 1995.

McPartland, J. M.; Brodeur, R. R. \& Hallgren, R. C. Chronic neck pain, standing balance, and suboccipital muscle atrophy--a pilot study. $J$. Manipulative Physiol. Ther., 20(1):24-9, 1997.

Nash, L.; Nicholson, H.; Lee, A. S.; Johnson, G. M. \& Zhang, M. Configuration of the connective tissue in the posterior atlanto-occipital interspace: a sheet plastination and confocal microscopy study. Spine (Phila Pa 1976), 30(12):1359-66, 2005.

Pontell, M. E.; Scali, F.; Marshall, E. \& Enix, D. The obliquus capitis inferior myodural bridge. Clin. Anat., 26(4):450-4, 2013.

Rutten, H. P.; Szpak, K.; van Mameren, H.; Ten Holter, J. \& de Jong, J. C. Anatomic relation between the rectus capitis posterior minor muscle and the dura mater. Spine (Phila Pa 1976), 22(8):924-6, 1997.

Scali, F.; Pontell, M. E.; Nash, L. G. \& Enix, D. E. Investigation of meningomyovertebral structures within the upper cervical epidural space: a sheet plastination study with clinical implications. Spine, 15(11):2417-24, 2015.

Scali, F.; Pontell, M. E.; Welk, A. B.; Malmstrom, T. K.; Marshall, E. \& Kettner, N. W. Magnetic resonance imaging investigation of the atlantoaxial interspace. Clin. Anat., 26(4):444-9, 2013.

Sui, H. J; Yu, S. B. \& Yuan, X. Y. Anatomical study on the connections between the suboccipital structures and the spinal dura mater. Chin.J. Anat., 31(4):489-90, 2013.

Xu, Q.; Liu, C.; Yuan, X. Y.; Chi, Y. Y.; Li, Y. F.; Zhang, J. F.; Sui, H. J.; Han, S. H.; Yu, S. B. \& Lin, X. T. Anatomical parameters of the rectus capitis posterior minor muscle based on a new magnetic resonance scan method. Int. J. Morphol., 35(3):1010-5, 2017.

Yuan, X. Y.; Yu, S. B.; Li, Y. F.; Chi, Y. Y.; Zheng, N.; Gao, H. B.; Luan, B. Y.; Zhang, Z. X. \& Sui, H. J. Patterns of attachment of the myodural bridge by the rectus capitis posterior minor muscle. Anat. Sci. Int., 91(2):175-9, 2016.

Zheng, N.; Yuan, X. Y.; Li, Y. F.; Chi, Y. Y.; Gao, H. B.; Zhao, X.; Yu, S. B.; Sui, H. J. \& Sharkey, J. Definition of the to be named ligament and vertebrodural ligament and their possible effects on the circulation of CSF. PloS One, 9(8):e103451, 2014.

Zumpano, M. P.; Hartwell, S. \& Jagos, C. S. Soft tissue connection between rectus capitus posterior minor and the posterior atlanto-occipital membrane: a cadaveric study. Clin. Anat., 19(6):522-7, 2006.
Corresponding author:

Prof. Sheng-Bo Yu

Department of Anatomy

College of Basic Medicine

Dalian Medical University

Dalian

CHINA

E-mail: ysbdmu@126.com

Corresponding author:

Prof. Hong-Jin Sui

Department of Anatomy

College of Basic Medicine

Dalian Medical University

Dalian

CHINA

Email: Suihj@hotmail.com

Received: 18-03-2018

Accepted: 04-05-2018 